політики, створенням умов для виконання органами місцевого самоврядування своїх повноважень шляхом розподілу бюджетних ресурсів між органами влади різного рівня.

\title{
Література:
}

1. Мельничук Л.М. Принцип децентралізації влади як ключовий вектор модернізаційних перетворень у системі державного управління соціальним розвитком регіонів. Регіональне та муніципальне управління. 2015. № 7-8 (21-22). С. 77-84.

2. Маслов А.О., Гладковська А.Т. Сутність, типи, форми, можливості і загрози децентралізації. Ефективна економіка. 2019. № 2. URL: http://www.economy.nayka.com.ua/pdf/2_2019/13.pdf.

3. Дорош У. До визначення поняття децентралізації влади. Ефективність державного управління. 2017. Вип. 3 (52). Ч. 1. С. 130-137.

4. Кізюн Л.І. Децентралізація влади та суміжні поняття. Право. Людина. Довкілля. 2019. Vol. 10(1). С. 28-34.

5. Горобець Н.О., Троян О.А., Страшок Є.В. Поняття децентралізації публічної влади в Україні. Юридичний науковий електронний журнал. 2019. № 5. C. 149-152.

DOI https://doi.org/10.30525/978-9934-26-074-2-29

\section{ПУБЛІЧНІСТЬ ФІНАНСОВО-ІНВЕСТИЦІЙНИХ ПРАВОВІДНОСИН ЯК ЧАСТИНИ ФІНАНСОВИХ ПРАВОВІДНОСИН}

\author{
Бліхар М. М. \\ доктор юридичних наук, дочент, \\ професор кафедри адміністративного та інформачійного права \\ Навчально-наукового інституту права, \\ психології та інноваційної освіти \\ Національного університету «Львівська політехніка» \\ м. Львів, Україна
}

Публічність фінансово-інвестиційних правовідносин як частини фінансових правовідносин зумовлена такими важливими чинниками: поперше, правове регулювання інвестиційних фінансів охоплює широкі сфери суспільного життя країни і $є$ частиною загального фінансовоправового регулювання грошових потоків (інвестиції входять до фінансової системи держави); по-друге, інвестиційна діяльність - це складова частина цілісного механізму управління фінансами відповідно до 114 
вибраних орієнтирів у розвитку країни (ії економіки, соціальної сфери); по-третє, інвестиції $є$ однією із системоутворювальних категорій фінансового права, яка за допомогою різноманітних проявів організаційноекономічного механізму та правової регламентації відповідних суспільних відносин має забезпечувати конструктивний розвиток України, іiї подальшу еволюцію згідно з цінностями об’єднаної Свропи.

Реалізація фінансових повноважень у процесі публічного володарювання - провідний напрям управлінської діяльності держави. Фінансова діяльність держави, як зазначено в літературі, грунтується на принципах публічного характеру, розподілу функцій між представницькими та виконавчими органами влади, пріоритетності публічних видатків щодо прибутків казни, фінансування безпеки держави, єдності фінансової діяльності та грошової системи держави, соціальної спрямованості, плановості, гласності [1, с. 9]. Це пояснює комплексну участь держави в регулюванні різноманітних фінансових відносин, незалежно від того, хто $\epsilon$ iіi прямими учасниками, адже результати цієї діяльності надзвичайно важливі для всіх суб'єктів фінансово-економічної діяльності. Потрібно також наголосити, що держава, поряд з тим, що через законодавчу гілку влади встановлює «власні правила гри», приймаючи законодавчі та підзаконні нормативно-правові акти, водночас виступає і власником отриманих коштів.

Як свідчить світова та вітчизняна практика, держава часто бере участь у підтримці діяльності учасників інвестиційного процесу (як за допомогою безпосереднього та активного втручання, так й через опосередкований вплив). Так, вона має можливість застосовувати специфічні методи державного управління інвестиційними процесами, наприклад, створення відповідного інвестиційного клімату, стимулювання попиту і пропозиції на певний вид інвестицій (в економіку, соціальну, наукову чи іншу сферу діяльності). Державі властива особлива економічна функція, яка дозволяе ій самостійно визначати напрями використання суспільного продукту, що важливо для загального розвитку економіки. Використання цього інструментарію, з іншого боку, є об'єктивною економічною необхідністю суспільства здійснювати розподіл і перерозподіл грошових фондів та участь в обігу фінансів для дотримання значущих пропорцій суспільного виробництва.

До ознак фінансової діяльності держави відносять, зокрема, базованість на фінансовому плані, пов'язаність 3 акумуляцією доходів i проведенням необхідних витрат, а також діяльність у правовій площині [2, с. 6]. Тому можна погодитися із твердженням О. Лукашева, що державне управління через використання правових форм і важелів у ширшому розумінні вже означає державне втручання як засіб реалізації 
владних повноважень, оскільки за вимогою обов'язкового дотримання правових норм і приписів однозначно стоїть можливість застосування державою свого примусу для дотримання цих норм [3, с. 185-191]. Таке втручання, що $є$ основою державно-правового примусу і здійснюване компетентними (вповноваженими) державними органами, має спиратися на принципи фінансово-правової відповідальності. Отже, держава через власну стратегію активного втручання в інвестиційну діяльність підприємств шляхом законодавчої ініціативи, бюджетного, валютного та податкового правового регулювання та інших важливих важелів визнає інвестиційну діяльність суттєвим чинником соціально-економічного зростання країни і здійснює на неї відповідний вплив. При цьому державні інституції не лише опосередковано беруть участь у реалізації інвестиційних програм (проектів), але й визначають масштаб та пріоритетність інвестиційно-інноваційного розвитку національного господарства, підвищують фінансове забезпечення необхідних суспільно значущих результатів тощо. Прямий вплив держави на інвестиційний процес здійснюється як безпосередньо через державний сектор економіки, так i через державні інституційні органи.

Держава як складний публічний інститут, що поєднує функціональні та організаційні складові, зобов'язана забезпечувати всі потреби суспільства. Вона повинна постійно й неухильно реалізовувати функції 3 планомірного і цілеспрямованого утворення, розподілу та використання державних централізованих та децентралізованих грошових фондів, тобто здійснювати фінансову діяльність. У цьому зв'язку варто згадати про наявний в літературі термін «публічні фінанси», який охоплює два види фінансів: державні та місцеві (муніципальні). У той час, коли вплив на економічний і соціальний розвиток місцевих утворень чиниться значною мірою за допомогою місцевих фінансів, державні фінанси забезпечують економічний та соціальний розвиток держави. Акцентуємо увагу на тому, що державні фінанси майже завжди стосуються грошей. При цьому регулювальна функція фінансів полягає у втручанні держави в процес відтворення (із застосуванням фінансового і бюджетного планування тощо). Ці напрями державного управління неможливо здійснювати без наявності відповідних джерел фінансування. Своєю чергою, через перерозподільні функції публічних фінансів та створення централізованих і децентралізованих публічних грошових фондів відбувається соціально спрямований перерозподіл грошових потоків у національному масштабі. Отож, політика держави у сфері інвестиційних фінансів спрямована на законодавче та інституційне забезпечення інвесторів й інших учасників інвестиційного процесу належними умовами для їх діяльності, на формування та розвиток вітчизняного інвестиційного ринку. 
У будь-якому разі фінансова діяльність держави, як і ії діяльність за іншими суспільно значущими напрямами, спирається на публічність державної влади як на ії визначальну ознаку. Фінансування народної життєдіяльності - об’єктивна суспільна необхідність, яку реалізує державно-владний апарат для забезпечення потреб народу, який проживає на території країни. Ця необхідність, знову ж таки, зумовлена реальними умовами буття суспільства, незалежними ні від волі цієї спільноти, ні від волі керівної верхівки, яка ії очолює. Зазначеними об'єктивними умовами продиктовано, що завдання, які стоять перед державою в конкретний історичний період, не можуть бути реалізовані без фінансів і їх раціонального використання. Товарно-грошовий характер суспільних відносин не залишає державі, територіальним громадам іншого вибору, аніж вступати у фінансові відносини, єдиним легітимним управлінським важелем яких є такий абстрактний публічний суспільний інститут, як держава, яка діє в особі органів, наділених нею ж відповідними повноваженнями. Фінанси як публічно-правова категорія проявляються тоді, коли держава у правовій формі здійснює послідовне накопичення i цілеспрямований планомірний поділ суспільних благ у вигляді видатків грошових фондів для забезпечення функціонування різних сфер суспільного буття.

Публічність в окресленому аспекті знаходить своє відображення через: 1) суб'єктний склад інвестиційної діяльності (суб'єктами-лідерами можуть виступати територіальні громади, держава та інші публічні суб’єкти); 2) категорію «фінанси» (як публічно-правовий термін); 3) спрямування інвестиційної діяльності (публічна мета в тій чи іншій мірі завжди їй властива); 4) фінансово-інвестиційний процес. До основних напрямів фінансово-правового регулювання у сфері інвестиційної діяльності належать: а) бюджетний вектор (відтворює ресурсну дієвість держави як інвестора, передусім через бюджетні асигнування); б) податковий напрям (характеризується заохочувально-стимулювальною i мобілізаційною спрямованістю); в) контрольно-деліктний вектор (виражає пошуково-аналітичний та карально-компенсаційний вплив); г) валютний напрям (демонструє динамізм, зовнішньовнутрішній дуалізм, безпосередньо пов'язаний 3 початком та результатами інвестування).

Оскільки роль держави в управлінні публічними фінансами $є$ владною, аналогічний характер (імперативний) мають і фінансовоправові норми. Держава як публічно-владний інститут визначає суб'єктам фінансово-інвестиційної діяльності єдино правильний варіант поведінки у фінансових правовідносинах, якого учасники цієї діяльності 
повинні в загальнообов'язковому порядку дотримуватись згідно із законодавчим полем.

Характерними ознаками фінансових приписів $€$ категоричність, загальнообов'язковість та караність за їх недотримання. При цьому право і правову сторону фінансової й інвестиційної діяльності суспільство сприймає як певний сумарний вектор інтересів держави та соціальноекономічних груп, задіяних у цих процесах безпосередньо чи опосередковано, оскільки до сфери фінансового впливу потрапляють майнові інтереси учасників цих правовідносин.

\title{
Література:
}

1. Зюнькін А. Г. Фінансове право: опорний конспект лекцій. Київ: МАУП, 2003. $160 \mathrm{c}$.

2. Савченко Л. А., Цимбалюк А. В., Шкарупа В. К., Глух М. В. Фінансове право: навч. посіб. Ірпінь: Акад. ДПС України, 2001. 85 с.

3. Лукашев О. Владно-майнова природа фінансово-правових відносин. Вісник Академії правових наук України. Харків: Право, 2009. № 3 (58). C. 185-191.

DOI https://doi.org/10.30525/978-9934-26-074-2-30

\section{GROUNDS OF ADMINISTRATIVE LIABILITY FOR INTELLECTUAL PROPERTY OFFENSES}

\author{
Gerasimenko O. O. \\ orcid.org/0000-0002-2504-0637 \\ Postgraduate Student at the Administrative, \\ Financial and Information Law Department \\ Kyiv National University of Trade and Economics \\ Kyiv, Ukraine
}

The domestic theory on administrative law currently does not form unanimous opinion as for the grounds of administrative liability. Modern scientific views on the nature, typology, structure, content and relationship differ significantly (in some cases - dramatically). At times, such a wide pluralism of scientific opinions served as a positive factor, which gave impetus to active scientific discussion and significantly expanded the boundaries of the idea as for the grounds of administrative liability and their role in application of administrative delict rules. However, over time, the situation began to require reassessment. The main task of scientific discussions, that is the 118 